\title{
EVALUATION OF IMPLEMENTING FINANCIAL SERVICES AUTHORITY AS A TAX SUBJECT
}

\author{
Ario Narabewa ${ }^{1 *}$, Yohanes ${ }^{2}$ \\ 1,2 Masters of Accounting, Faculty of Economics and Business, University of Indonesia, Indonesia \\ Email corresponding author: arionarabewa@outlook.co.id
}

\begin{abstract}
This researchis conducted to examine the determination of Otoritas Jasa Keuangan as a tax subject and object by the Directorate General of Taxes. DGT determines levies by the OJK on the financial sector related to tax objects. This can lead to double taxation problem depending on the remaining levies of the current year and the following year's budget must be submitted by the OJK to the Treasury. This study employs the state sovereignty theory to request that this stipulation is under statutory regulations. Case study is chosen as the research strategy to deepen the study of this determination phenomenon more deeply and can provide advice to OJK and the Directorate General of Taxes. The data were collected by interview method and document study. The result of this study found that the OJK as an entity has the function to conduct pure administrative tasks. Theresult of this translation shows that OJK's levy is part of PNBP, thus it cannot be used using object tax.
\end{abstract}

Keywords: Otoritas Jasa Keuangan (OJK), Tax Subject, Tax Object, State Institutions.

\section{INTRODUCTION}

The general definition of tax is a contribution that must be given by individuals or entities under an obligation and based on statutory regulations. The results of taxation do not provide direct compensation to taxpayers but are used for the state and prosperity of the people. Taxpayers are parties in a country that have an obligation in paying taxes which will be a source of state funding and national development.

Tax revenue will be used to finance the construction of facilities utilized by all sectors of community. Every citizen living in one country can utilize and enjoy the facilities provided by the government. In order construct these facilities, the government employs financing from tax revenue. In addition to public facilities, the government also utilizes tax revenues to provide subsidies for basic needs to the public, as well as to pay state debt abroad. According to the definition above, it can be concluded that tax plays an important role for a country in carrying out state activities and running the government. 
Pemerintah Republik Indonesia (2008) through Law No. 7 of 1983 which was last amended to become Law No. 36 of 2008 concerning Income Taxes (here in after referred to as the Income Tax Law) states that the subject of domestic taxation consists of individuals residing in Indonesia and entities established in Indonesia. Pemerintah Republik Indonesia (2008) through Law No. 6 of 1983 which was last amended to become Law No. 28 of 2007 concerning General Provisions for Taxation (here in after referred to as the KUP Law) states that the definition of a body is a group of people and/or capital that constitutes a unit that owns business or does not own business including limited liability companies, limited liability companies, other companies, BUMN or BUMD by name and in any form, firm, partnership, cooperative, pension fund, partnership, association, foundation, mass organization, socio-political organization, or other organizations, institutions and other forms of bodies including collective investment contracts and permanent establishments. However, there are certain units that are exempt from the subject of corporate tax, namely government bodies that meet the following criteria: (1) Its formation is based on statutory provisions; (2) The funding comes from the State Revenue and Expenditure Budget or the Regional Revenue and Expenditure Budget; (3) The budget is included in the budget of the Central Government or Regional Government; (4) The books are checked by the state functional supervision apparatus;

There is a polemic between the Directorate General of Taxes (DGT) and OJK on the subjectof OJK. It should be considered by the government and to act in a fair, transparent and accountable manner. The research problem elaborated in this study is the polemic between DGT and OJK regarding the establishment of OJK as a tax subject (Firdaus 2016; and Zuraya 2017). DGT stipulates that the levies imposed by OJK on the financial services sector are objects of income tax, which can lead to double tax issues because the remaining levies for the current year and the following year's budget must be deposited by the OJK to the State Treasury. For this polemic, until the end of December 2017 the OJK still performs budget efficiency in order to reserve money to pay taxes. The situation is reckoned to disrupt the work and performance of the OJK as an institution that functions to organize an integrated regulatory and supervision system for all activities in the financial services sector (Zuraya, 2017).

This study is aimed to analyze and evaluate aspects of taxation at OJK, so that it can provide views and recommendations on tax treatment at OJK to lessen the polemic between OJK and DGT and there is no double taxation.

This research was conducted by researchers to study and answer research the following questions: Why is OJK as an institution established by the government through the law determined as a tax subject? And why OJK cannot be categorized as an entity that is excluded as a tax subject?

This research employs a mixture of qualitative method and quantitative method. Qualitative method is a research method by collecting descriptive data such as interviews and conducted using 
analysis, data collection is carried out directly on the object of this study. Quantitative method is a method that links research objects with existing theories, the data used are in the form of secondary data that is available.

Mixed method is used in this study because the point of view and the method is very appropriate to describe research questions and is the most effective method of providing complete, balanced and useful information. The data collection method in this study is carried out through interviews and collecting quantitative data in the form of both softcopy and hardcopy documents.

Ellet (2007) states that the benefits of research using case studies are:

1. Evaluation

2. Decision making

This research is expected to be used as an input and consideration for the Directorate General of Tax (DGT) to improve aspects of income taxation for institutions established by the government, specifically the taxation aspects of OJK levies on the financial services sector.

For OJK, the results of this study can be used as an input and evaluation in carrying out taxation rights and obligations to avoid double taxation without harming the state and OJK's function as an institution that regulates, supervises, inspects, and investigates the financial services sector.

In addition the benefits indirectly can add insight and knowledge for academics in the scope of taxation. Another benefit of this research is for the researchers themselves, to be able to develop knowledge and knowledge and be able to apply it to the case studies under study.

The difference between this research and previous research conducted by Rahmayati (2011) is that OJK is an institution that is different from $\mathrm{BI}$ and $\mathrm{BLU}$ and the surplus of $\mathrm{BI}$ income subject to tax is regulated in the income tax law. The research conducted by Rahmayati (2011) only conducted a content analysis study through a study of taxation law regulations and did not conduct interviews.

\section{LITERATURE REVIEW AND HYPOTHESIS DEVELOPMENT}

Kusumo (2016) states in carrying out its function, the stateserve the needs of the community. Therefore, the public interest must take precedence over personal interests and it is necessary to always safeguard national interests for present and future generations. It is also stating that a sovereign and independent state has the authority to regulate the people, objects, property, events, actions and incidents in their own country.

The sovereign state has the authority to regulate taxation jurisdiction over the person, property or object in its territory. The taxation jurisdiction is stated in article 23A of the Constitution of the Republic of Indonesia which is the power and authority of the state to draft, enforce and implement tax legislation in Indonesia. The basic legal framework for taxation requires it to follow the rules of law. At OJK which is an institution established by the government and taxed on its income, the 
rules of law in determining OJK as a subject and object of tax need to be further investigated. This is done to lessen cause polemics between the DGT and OJK and there is no double tax where that would certainly be detrimental to the OJK itself.

Palan (2002) mentions that the modern state system can commercialize state sovereignty and form a strategy to free taxation by making their country a Tax Heaven Country. Commercialization by a country is not wrong because it does not deviate from the principle of sovereignty of a country and reflects the principles of national sovereignty in the era of mobile capital.

Rohatgi (2005) stated that in the taxation system, legal system, and practice there is often no harmony and can cause a conflict. Furthermore, they are not clearly described and are subject to interpretation.

Based on its principle, the state has the sovereignty to impose taxes on all forms of business in that country. Tambunan (2019) stated that the sovereignty of a country to impose a tax is an absolute nature that is bound in the existence of the country's sovereignty itself. The sovereignty of a country is born at the same time as that country and is recognized by various countries for its existence. In other words, tax sovereignty is born with the existence of a country. In carrying out tax collection, a country needs to uphold the principle of justice both in the principle of legislation and in carrying out its daily practice. To receive a fair tax collection, the government needs to recognize that the collection is carried out in a general and equitable manner (Rahmayati, 2011).

According to the Income Tax Law, the subject to taxation are individuals, undivided inheritance, entities, and BUT. The individuals are Indonesian citizens or foreign nationals who are in the territory of Indonesia for 183 days or more in a year or have the intention to settle in Indonesia. Undivided inheritance is a substitute entity entitled to the assets of the inheritance; the determination of the tax subject for the inheritance is for administration purposes of tax collection. The subject of inheritance tax that has not been shared is the substitute tax subject of the tax subject leaving the inheritance. Agency in this definition is an agency established or domiciled in Indonesia. In the Income Tax Law there are also exceptions for government agencies/bodies with the following conditions: (1) Its formation is based on statutory provisions; (2) The funding will be sourced from the APBN or APBD; (3) The revenue is included in APBN or APBD; and (4) The books are checked by the state functional supervision apparatus.

Hatta (2017) stated that double taxation can be interpreted as any form of billing or other charges and levies more than once, both in the form of multiple and more on a fiscal fact in accordance with the country of the tax collector. It can also mean the collection or taxation of one or the same transaction in two or more countries on different tax subjects.

Vogel (1997) stated that there are two types of double taxation i.e. juridical double taxation and economic double taxation. The example of juridical double tax is where one person is taxed by 
two or more countries on the same income. Meanwhile, example of economic double taxation is where one country taxes two different people on the same income or one country taxes twice the income the same one.

Double taxation is caused by differences in the tax system, which is a clash between subjective taxes and objective tax, or if the tax systems are the same, double taxation can still arise if there are different definitions of certain meanings.

For the OJK (Financial Services Authority), there are two deposits given to the state namely through income tax and also aftertax surpluses will be deposited back into the state treasury. Therefore, researchers are interested in evaluating the determination of the OJK as a tax object and object.

A number of previous studies used by researchers as a reference in this study include research which states that in condition CAR (Credit Adequacy Ratio) of Bank Indonesia is sufficient, Bank Indonesia's surplus can be deposited to the government, so that if the surplus is subject to income tax again, it will occur which is called double taxation Rahmayati (2011).The study is conducted in 2011 which in that year OJK is not yet established by the government and some functions of OJK were still carried out by Bank Indonesia.

Dracea (2009) stated that in determining the structure of taxation, the state has its own assumptions depending on the function of the tax subject. The assumptions given by the state are primarily about social protection for its citizens.

Another research that is used by the researcher as a reference is a study done by the Resmi (2013) which states that BLU has an obligation to carry out tax deductions but is not taxed on their own income even though the income is derived from income derived from the results of public services outside the State Budget/APBD.Similar to OJK, BLU is an agency within the government that provides services to the community in the form of the supply of goods and/or services sold without prioritizing profit seeking and in carrying out its activities based on the principles of efficiency and productivity.

The difference between this research and previous research conducted by Rahmayati (2011) and Resmi (2013) is that previous research discuss about Bank of Indonesia and BLU while this study discuss about which OJK is an institution that is different from $\mathrm{BI}$ and $\mathrm{BLU}$ and the surplus of $\mathrm{BI}$ income subject to tax is regulated in the income tax law. The research conducted by Rahmayati (2011) only conducted a content analysis study through a study of taxation law regulations and did not conduct interviews.

Problems related to the determination of OJK as a tax object by the DGT are analyzed using the theory of state sovereignty (Kusumo, 2016), to be able to see the suitability of the application with 
the KUP law, PPh law, and OJK law. Thus, it can produce an evaluation and advice for the tax treatment of government institutions especially at OJK.

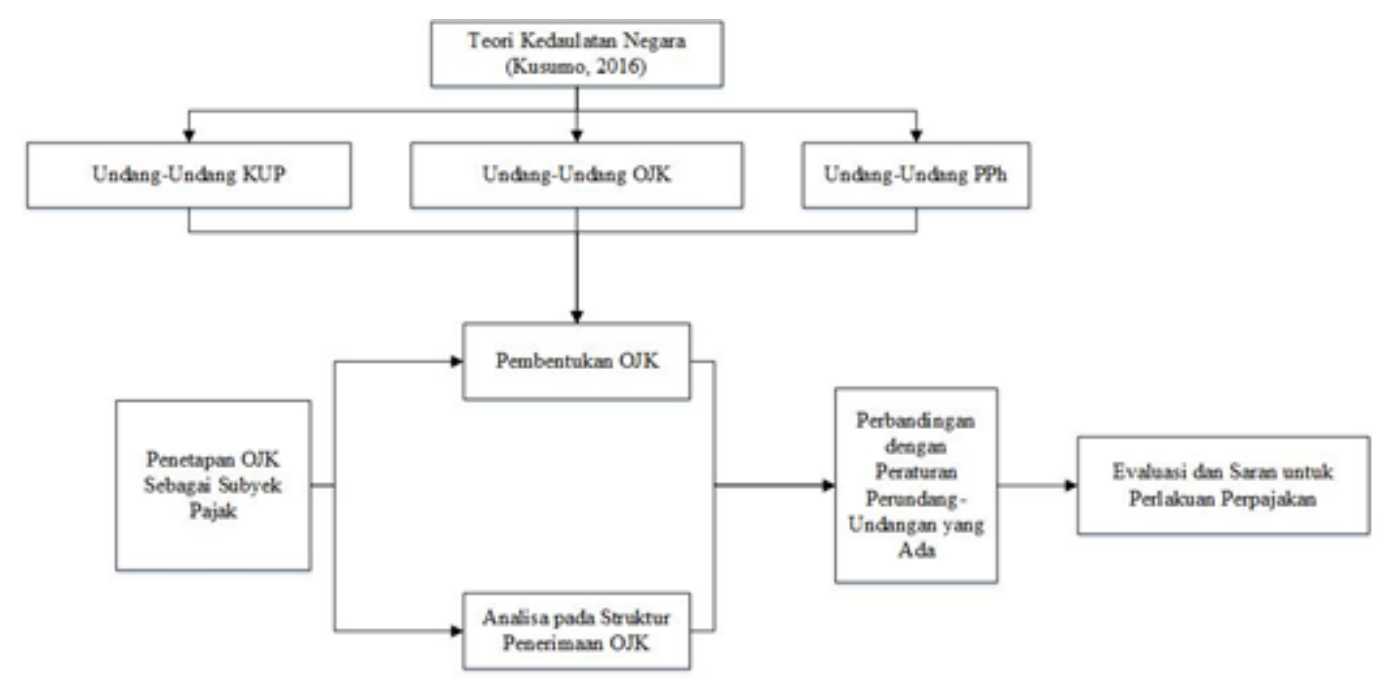

Picture 1.Conceptual Framework

\section{RESEARCH METHOD}

This research strategy is a case study approach. By using case studies as research strategies, this research carries out a careful investigation of an event that is happening (Creswell, 2010). Case study is an empirical analysis that investigates complex phenomena, especially when the boundaries between phenomena and context are not very clears (Yin, 2011). This study employs a single case study and single case analysis. The object of this research is OJK, institution that oversees and regulates the financial services sector. OJK is given the right to collect income from the financial services sector in performing its duty. The case study is chosen as the research approach because the problems are inherent in the tax treatment of OJK that exist in the research questions can only be answered through case studies. Case studies allow researchers to dig deeper and in more detail about the causes of Directorate General of Taxation that confirms the OJK as a tax object and how tax treatment should be in the collection of OJK levies and for this case study also researchers can provide recommendations for implementing rules on taxation so no double taxation on OJK collection income.

The research approach used in research is a qualitative approach. Qualitative data is intended to analyze and evaluate OJK as an Institution formed by the government through laws determined as tax subjects and tax treatment that can be applied to OJK levied income towards the financial services sector so that double taxation does not occur.

The data collecting method used in this study is within-method triangulation where the research method employs a qualitative approach of more than one approach (Dezin in Shauki, 2017). The data collection methods include: 
a.The first data collecting method is using a document study. It is a method of gathering information by collecting and analyzing various documents related to this research. The documents used in this study are in the form of regulations which form the basis for the establishment of the OJK, laws related to income tax, and documents deemed necessary.

b.In addition to document studies, this research also utilizes data obtained from interviews. The interview is a data collection technique conducted by giving direct questions to informants related to the object of research. This study conducted an interview with the Directorate General of Taxes.

The data used in this research are qualitative and quantitative data. The data used in this study are primary and secondary data. The data used in the form of aspects relating to taxation of OJK are obtained from various sources from legislation and from other sources, as well as from interviews about aspects of any aspect relating to OJK taxation. The data in question is the rules and regulations both on taxation laws and laws related to OJK.

The data analysis of this study is conducted qualitatively using content and descriptive analysis. Content analysis is a discussion of written information both from written information and from the mass media. Whereas descriptive analysis processes information about the distribution of all documents and journals presented together with analytic findings in the discussion (Seuring \& Gold, 2012). The results of interviews and documents, this study will be described to find an evaluation of the determination of OJK as a tax subject. Data processing is performed using the document review method by reviewing the literature on tax regulations. Data analysis is developed descriptively when analyzing factors outside existing taxation regulations and contributing as important as existing taxation factors in applying taxation aspects to OJK levies on the financial services sector.

Pemerintah Republik Indonesia (2011) in Law No. 21 of 2011 concerning OJK (here in after referred to as the OJK Law) states that OJK is an independent institution and is free from interference from other parties, which has the functions, duties and authority to regulate, supervise, examine and investigate. The purpose of the establishment OJK is that the implementation of financial services in the financial services sector can be organized regularly, fairly, transparently and accountably, and can create a sustainable and stable financial system.

Article 34 of the OJK Law states that the OJK budget is from the State Revenue and Expenditure Budget and/or levies from parties conducting activities in the financial services sector. The levies received by OJK from those who carry out activities in the financial services sector are used to finance operational, administrative, asset procurement, and other supporting activities in the following fiscal year. To determine the budget according to Article 36 of the OJK Law, the OJK first requests the approval of the House of Representatives. 
Article 3 paragraph 3 of the OJK Law states that if the received levies exceed the budget for the following year, the excess is deposited to the State Treasury. In depositing the State Treasury, OJK will coordinate with the Minister of Finance.

OJK itself is formed not apart from the economic crisis that hit Indonesia in 1998 and 2008. The crisis had an overall impact on the economy and national development. Based from the two crisis events, it is important to conduct an independent and professional financial service sector management. In addition, the explanation of the OJK Law explains that the process of globalization in the financial system and the rapid progress in information technology and financial innovation has created a financial system that is complex, dynamic, and inter-related financial sub-sectors both in terms of products and institutions are also a factor which prompted the urgency of establishing OJK.

According to Sutedi (2014) the initial idea for the formation of OJK is the result of a compromise over an agreement not reached in the discussion of the Bank Indonesia Law by the DPR. The administration of President Habibie gave a Draft Bank Indonesia Act in which the Bank Indonesia Act was given independence status. In addition, the Bank Indonesia Bill also issues a supervisory function from the central bank. The establishment of OJK has the principle of integration and coordination in banking supervision so that the financial services sector can be monitored and given more effective regulation.

\section{RESULT AND DISCUSSION}

The interview is conducted with the Directorate General of Taxes represented by representatives of the Directorate of Taxation Regulations II. To become an entity that is exempt from tax subjects, an entity must meet all the elements required in Article $2 \mathrm{PPh}$. Initially, OJK has fulfilled all the requirements in the Act. OJK has fulfilled the first requirement, namely its formation based on laws and regulations in which OJK is formed based on OJK Law.

The second requirement is that the budget comes from the APBN and/or APBD; initially in 2014 and in 2015 the OJK fulfilled this requirement because in that year the OJK did not have a levy and the budget came from the APBN. In that year the OJK is not subject to corporate taxation and obtained a treasurer NPWP. In 2016 OJK already had a levy so that it no longer used the State Budget, this made OJK no longer qualified as an entity that was excluded from the tax subject. OJK collection income for the current year can be used as operational costs or budget for the following year, if there is a difference between the income of current year levies and operational costs for the following year, the difference must be deposited in the state treasury and is a form of PNBP. So far, the difference from the levies is not actually deposited to the state treasury and OJK maximizes the difference so that the OJK in preparing the budget is deemed not on target. Thus, it is considered unfair if during a 
surplus the OJK uses it to the maximum and if there is a deficit then asks for the budget through the state budget. It is possible for OJK to be eligible if it runs deposits in a country mandated by its laws.

In determining it as a tax subject, the determination is carried out in a position by the DGT regional office in this case the Directorate General of Tax of the Central Jakarta Regional Office. After being determined as a tax subject, OJK status is equivalent to a private entity that does not have mandatory levies like SOEs or Government Agencies. The status is the same as the Legal Entity State University which was originally a mandatory levied and has a Treasurer NPWP but after becoming a legal entity and being a tax subject no longer has a mandatory levied obligation.

Mainly, financial supervisory institutions in various countries are not taxed. That is because financial supervisory institutions such as OJK are nonprofit institutions and aim to help the government supervise existing financial institutions. Out of the 5 countries above, only South Korea that is not taxed. Based from its financial statement, the tax paid by the South Korean Financial Supervisory Service (FSS) is a return to the country. In the 2017 Financial Supervisory Service (FSS) financial statements, it was noted that the balance before tax in 2017 and 2016 amounted to 279 million KRW and 247 million KRW respectively, all of which was deposited to the country through tax. The following are similar institutions with OJK in various countries and their tax treatment:

Table 1. Application of Taxation for Taxation Authorities in Various Countries

\begin{tabular}{|c|c|c|c|}
\hline No & Institution & Country & Taxation \\
\hline 1 & $\begin{array}{l}\text { Australian Prudential } \\
\text { Regulation Authority (APRA) }\end{array}$ & Australia & $\begin{array}{l}\text { APRA is exempt from all forms of } \\
\text { taxation except the Fringe Benefit } \\
\text { Tax (FBT) and the Goods and } \\
\text { Services Tax (GST) }\end{array}$ \\
\hline 2 & $\begin{array}{l}\text { Office of the Superintendent } \\
\text { of Financial Institutions } \\
\text { (OSFI) }\end{array}$ & Canada & $\begin{array}{l}\text { There is no tax burden and tax } \\
\text { explanation on the financial } \\
\text { statements }\end{array}$ \\
\hline 3 & $\begin{array}{l}\text { Financial Service Agency } \\
\text { (FSA) }\end{array}$ & Japan & $\begin{array}{l}\text { It is an entity that is under the } \\
\text { ministry and is not subject to income } \\
\text { tax. }\end{array}$ \\
\hline 4 & $\begin{array}{l}\text { Financial Conduct Authority } \\
\text { (FCA) }\end{array}$ & UK & $\begin{array}{l}\text { It is a subject to corporate tax } \\
\text { because regulatory activities are not }\end{array}$ \\
\hline
\end{tabular}




\begin{tabular}{llll}
\hline No & Institution & Country & Taxation \\
\hline & & "trading" activities. \\
\hline 5 & Financial Supervisory Service & South Korea & All current year's income differences \\
& (FSS) & and current year's expenses are \\
& & deposited to the country through \\
& taxes.
\end{tabular}

Source : data researchers processed

Indonesia as a sovereign country has sovereignty in determining taxation within its own country, including in determining the taxation of OJK. This sovereignty is reflected in the formation of taxation laws both laws and other regulations. For this reason, the principle of justice must be upheld in living the rules. OJK stated in its Financial Statements that according to a letter issued by the Minister of Finance regarding the OJK Tax Obligation Status stated that: (1) OJK is included in the definition of institutions that are included in the category of agency. It is a body that does not do business. OJK also does not meet as an entity that is excluded as a tax subject. Therefore OJK is determined as the subject of income tax; (2) OJK levies that have been submitted by letter from the Director General of Taxes are income that can be subject to income tax.

The Director General of Taxes through a letter answering OJK's Taxation Status and Obligations revealed that: (1) Fee imposed by OJK on the financial services sector are income which is subject to tax; and (2) Provision of APBN funds provided by the government to OJK is not non-income that is subject to tax.

From the description of the letter of the Minister of Finance and the Director General of Taxes above, it can be concluded that OJK is established as a domestic tax subject, that is, a body established and domiciled in Indonesia.

According to KUP and in the elucidation of Article 2 paragraph 1 PPh mentions the entity is: "A group of people and/or capital that constitutes a unit whether doing business or not doing business that includes a limited liability company, other company, state-owned enterprise or business entity regionally owned by name and in any form, firm, partnership, cooperative, pension fund, partnership, association, foundation, mass organization, socio-political organization or other organization, institutions and other forms of entities including collective investment contracts and permanent establishments".

OJK is stipulated as a tax subject because it meets the definition of the body, which is an institution that carries out supervisory activities and financial services sector regulations. The body 
shape of the OJK is clearly written in the OJK Law which says that the OJK is an independent institution.

Judging from the position written in the OJK Law, OJK is an independent institution that performs its duties cannot be intervened by any party. This means that OJK has the authority to implement policies without interference from other parties. In the Decision of the Constitutional Court No. 25 of 2014 states that OJK is an independent state institution, and it is classified as a State institution because it was formed by the state in order to carry out its function as a supervisor in the banking sector. While it's independent nature is granted to prevent interference from other parties in making policies and decisions.

According to the description above, OJK has fulfilled the requirements as a State Institution which can also be interpreted as an independent government body that has the function of organizing an integrated regulation and supervision system for all activities in the financial services sector.

OJK itself was formed based on the urgent situation to respond to the crisis that occurred in Asia in 1997-1998. The establishment was based on the mandate of Law Number 3 of 2004 concerning Amendment to Law Number 23 of 1999 concerning Bank Indonesia, where the government was given the mandate to establish an independent institution to oversee the financial services sector under the name of OJK. The mandate was realized through the OJK Law. In its establishment the Authority is given the function of organizing an integrated regulatory and supervision system within the financial services sector. As for carrying out its functions, OJK has the task of regulating and supervising: (1) Financial service activities in the Banking sector; (2) Financial services activities in the capital market sector; and (3) Financial service activities in the insurance sector, pension fund, financial institutions and other financial service institutions.

These functions and tasks are given in order to achieve the objectives of the establishment of the OJK. This all activities in the financial services sector: (1) Organized regularly, fairly, transparently and accountably; (2) Being able to realize a financial system that is growing in a sustainable and stable manner; and (3) Able to protect the interests of consumers and society.

Based on the Income Tax Law, government agencies that are excluded as tax subjects have a condition, one of which is the formation of the law. OJK has fulfilled these requirements by establishing it according to the OJK Law.

In carrying out its operations OJK obtains a budget/revenue derived from the State Revenue and Expenditure Budget and/or levies from the financial services sector. Revenues derived from levies from the financial services sector can be used for costs from the activities of OJK the following year, if the current collection fees for the current year exceed the needs of OJK the following year, the excess must be deposited in the state treasury. 
The State Revenue and Expenditure Budget is an annual revenue and expenditure plan that will be used by the government and has been approved by the House of Representatives. Furthermore, Law Number 1 of 2004 concerning State Bylaws states that the APBN is managed and is the responsibility of the Minister/Institutional Chair for financial management of the relevant state ministries/institutions.

The following is a scheme for OJK's Income:

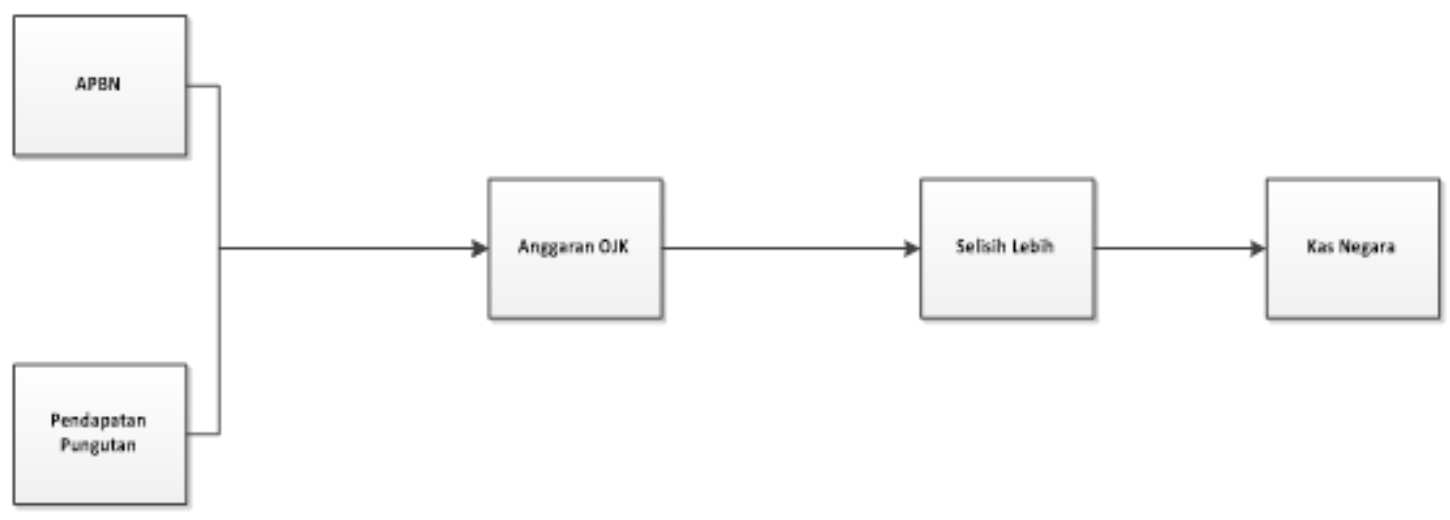

Picture 2. Scheme for OJK's Income

In addition to the source from the APBN, the budget of OJK can also come from levies on those who do business from those who do business in the financial services sector. Those who conduct business in the financial services sector are required to pay levied by the OJK. Types of fees imposed by OJK include licensing fees, approval fees, registration fees, endorsements, and reviews of corporate action plans as well as annual costs in the context of regulation, supervision, inspection and research.

At the beginning of the establishment of OJK, they were using APBN fund as operational costs. It is stated in the OJK Law article 35 paragraph 3 "to support OJK operational activities, the Government can place initial funding to OJK". The APBN fund is used to finance operational costs for 2013 and 2014 in the amount of $\operatorname{Rp~1,645,293,987,000~and~Rp~2,408,282,840,000~or~100\% ~of~the~total~}$ budget for that year. This was during the time when financial services authorities did not yet receive revenue from levies financial services sector. In 2014 OJK received a fee from the financial services sector amounting to $\operatorname{Rp} 2,009,326,213,485$ which was then used to finance the 2015 budget. However, this revenue is not sufficient for 2015 budgetary purposes. Thus, in 2015 the OJK still received funds APBN in the amount of $\mathrm{Rp} 1,475,300,000,000$ or as much as $46 \%$ of the total OJK budget in 2015. Furthermore, in the following years the OJK levies have been able to fully meet the budget of the following year so that they no longer use APBN funds.

Sources of financing for OJK from 2013-2018 are as follows: 
Table 2. Sources of OJK Financing

\begin{tabular}{cccccc}
\hline Year of & \multicolumn{2}{c}{ APBN } & \multicolumn{2}{c}{ Charges } & Total \\
\cline { 2 - 6 } Budgeting & Rp & $\%$ & Rp & $\%$ & $R p$ \\
\hline 2013 & 1.645 .293 .987 .000 & 100 & - & 1.645 .293 .987 .000 \\
\hline 2014 & 2.408 .282 .840 .000 & 100 & - & 2.408 .282 .840 .000 \\
\hline 2015 & 1.475 .300 .000 .000 & 46 & 2.009 .326 .213 .485 & 54 & 3.754 .626 .213 .485 \\
\hline 2016 & - & - & 3.938 .899 .360 .221 & 100 & 3.938 .899 .360 .221 \\
\hline 2017 & - & - & 4.371 .486 .105 .348 & 100 & 4.371 .486 .105 .348 \\
\hline 2018 & - & - & 4.977 .186 .842 .281 & 100 & 4.977 .186 .842 .281
\end{tabular}

Source: Financial Statement of OJKin 2018

Article 35 Paragraph (1) of the OJK Law states that the OJK budget can be used to finance operational, administrative, asset procurement and other supporting activities. OJK through the 2018 annual report explains these burdens include: (1) Operational expense are cost incurred to carry out the functions, duties and authority of the OJK, such as regulation, supervision, law enforcement, education and consumer protection; (2) Administrative activities expenses are cost incurred to finance office activities, remuneration payments, education and training, organizational development and human resources; (3) Asset procurement activity expenses are costs incurred from the activities of buying and maintaining assets, including depreciation and amortization expenses; (4) Other supporting activity expenses are cost incurred to carry out OJK activities that do not include categories number 1 to number 3 above.

Furthermore, if the current year's OJK levy revenue exceeds the costs of the following year, the difference from the current year's fees and the following year's fees must be deposited in the state treasury and in the deposit the OJK needs to coordinate with the Minister of Finance.

As for the realization of OJK levies and fees in 2016-2018:

Table 3. Implementation of Revenue Collection and Budget of OJK

\begin{tabular}{lllr}
\hline $\begin{array}{c}\text { Year of } \\
\text { Budgeting }\end{array}$ & $\begin{array}{c}\text { Implementation of } \\
\text { Previous Year's } \\
\text { Revenue(Rp) }\end{array}$ & $\begin{array}{c}\text { Implementation of the } \\
\text { Current Year's } \\
\text { Budget(Rp) }\end{array}$ & $\begin{array}{r}\text { Difference(Rp) } \\
\end{array}$ \\
\hline 2016 & $3.938 .899 .360 .221 ;$ & $3.938 .899 .360 .221 ;$ & $0 ;$ \\
\hline 2017 & $4.381 .237 .487 .467 ;$ & $4.381 .237 .487 .467 ;$ & $0 ;$ \\
\hline 2018 & $5.018 .299 .500 .129 ;$ & $4.977 .186 .842 .281 ;$ & 41.112 .657 .848 \\
\hline
\end{tabular}

Source: OJK's Financial Statements for 2016-2018 
In 2016 budget, based on the decision of the board of commissioners on December 21, 2015, the 2016 OJK budget was Rp 3,934,100,000,000.00. In 2015 OJK levies exceeded the target of Rp 4,627,312,947.00. The excess was used as an additional payment for the 2016 OJK Agency's PPh tax burden so that in the realization of funds used by the OJK in 2015 amounted to Rp $3,938,899,360,221.00$. In the 2016 budget ceiling OJK realized the receipt of fees amounting to Rp $4,381,237,487,468.00$. The budget set at the 2017 budget is $\operatorname{Rp~} 4,371,486,105,348.00$. There is a difference between the realization of 2016 collection fees and the 2017 budget ceiling of Rp $9,751,382,119.00$. The difference was used by the OJK to pay installments to the Corporate Income Tax and has been conveyed to the chairman of the House of Representatives commission XI, so that the realization of the use of the OJK budget for 2017 amounted to Rp 4,381,237,487,467.00. In 2018, there will also be a difference between the realization of 2017 revenue and the 2018 budget ceiling, the difference amounting to $\mathrm{Rp} 41,112,657,848.00$. The difference has been deposited in the state treasury on December 31, 2018.

OJK funding according to OJK Law Article 34 Paragraph (2), Article 37 along with its explanation is from the APBN and/or levies of parties conducting activities in the financial services sector. This means that in terms of OJK funding, it can only be sourced from the state budget and can also only be sourced from levies and can also be sourced from both. OJK funding which is only sourced from the APBN is not appropriate because there are levies that should be charged to the parties concerned. Judging from the function of the OJK itself, the imposition of levies is a logical consequence because at the time the financial sector actors collected will benefit from the OJK levies.

In terms of its management the levies collected by the OJK have met the standards of state financial management which in their application have accountability elements that are resultsoriented, professionalism, proportionality, openness in managing state finances and audits by independent and independent auditing bodies. This makes OJK levies and budgets meet the rules of managing state finances in the APBN itself.

In Article 38 of the OJK Law, OJK has an obligation to prepare financial reports consisting of annual financial reports and annual financial reports with the reporting date of January 1 to December 31. The annual financial statements that have been prepared OJK are required to be audited by the Supreme Audit Board or the Public Accounting Firm appointed by the Supreme Audit Board. In addition to OJK's financial reports, it is also obligatory to compile activity reports consisting of monthly, quarterly and annual activity reports. For quarterly financial reports, it must be submitted to the House of Representatives as a responsibility to the people of Indonesia and annual financial reports to the President and the House of Representatives. According to the explanation above Bookkeeping compiled by OJK Bookkeeping that has been examined by the state functional apparatus. 


\section{CONCLUSION}

This research results show that OJK as an institution that carries out state functions and is mandated by law, which makes it a not a pure tax subject. OJK needs to coordinate with the Minister of Finance and the Coordinating Minister for the Economy to get the right tax treatment so that there is no double taxation imposed on OJK.

This study has a limitation by not only analyzing the taxation of OJK and not to dissect further the contents of OJK financial statements. This limitation occurs because this research only focuses on the background of the problem that occurs indetermining OJK as a tax subject by the Directorate General of Taxes. This study only conducted interviews with the Directorate General of Taxes and did not interview OJK because they did not respond the interview request. The limitations of this study are expected to be able to provide an overview for further research in order to provide a more in-depth analysis of the taxation status of OJK. Thus, it can provide improvement to the taxation status of OJK or other government auxiliary institutions formed by the law and function as executor of state interests.

\section{REFERENCES}

Creswell, J. W. 2010. Research design: pendekatan kualitatif, kuantitatif, dan mixed. Yogjakarta: PT. Pustaka Pelajar.

Ellet, W. 2007. The case study handbook: How to read, discuss, and write persuasively about cases. Harvard Business Press.

Dracea, N. M. 2009. Taxation and fiscal pressure. Revista Finance-Challenges of the Future, (9).

Firdaus. 2016. Kontroversi pengenaan pajak bagi OJK. Retrieved from http://analisis.kontan.co.id/news/kontroversi-pengenaan-pajak-bagi-ojk?page=1

Hatta, H. 2017. KONTRADIKTIF PENERAPAN HUKUM PAJAK BERGANDA DI INDONESIA. Jurnal Al-Ishlah, 19(2).

Pemerintah Republik Indonesia. 2007. UNDANG-UNDANG NOMOR 28 TAHUN 2007 TENTANG PERUBAHAN KETIGA ATAS UNDANG-UNDANG NOMOR 6 TAHUN 1983 TENTANG KETENTUAN UMUM DAN TATA.

Pemerintah Indonesia. 2008. Undang-undang No. 36 Tahun 2008 tentang Perubahan Keempat atas Undang-Undang No. 7 Tahun 1983 tentang Pajak Penghasilan. Jakarta: Departemen Keuangan Republik Indonesia.

Pemerintah Indonesia. 2011. Undang-undang No. 21 Tahun 2011 tentang Perubahan Otoritas Jasa Keuangan. Jakarta: Departemen Keuangan Republik Indonesia. 
Pemerintah Republik Indonesia. 2014. Laporan Keuangan Publikasi. Jakarta : Otoritas Jasa Keuangan Pemerintah Republik Indonesia. 2015. Laporan Keuangan Publikasi. Jakarta : Otoritas Jasa Keuangan Pemerintah Republik Indonesia. 2016. Laporan Keuangan Publikasi. Jakarta : Otoritas Jasa Keuangan Pemerintah Republik Indonesia. 2017. Laporan Keuangan Publikasi. Jakarta : Otoritas Jasa Keuangan Pemerintah Republik Indonesia. 2018. Laporan Keuangan Publikasi. Jakarta : Otoritas Jasa Keuangan Kusumo, A. T. S. 2016. Reformasi Birokrasi Perpajakan Sebagai Usaha Peningkatan Pendapatan Negara Dari Sektor Pajak. DEMO 2 JURNAL, 95.

Palan, R. 2002. Tax havens and the commercialization of state sovereignty. International organization, 56(1), 151-176.

Rahmayati, F. 2011. BANK INDONESIA SEBAGAI SUBJEK DAN OBJEK PAJAK PENGHASILAN. UNIVERSITAS AIRLANGGA.

Resmi,Siti. 2013. Perpajakan Teori dan Kasus. Salemba Empat. Jakarta

Rohatgi, R. 2005. Basic international taxation (Vol. 1). Richmond Law \& Tax.

Seuring, S., \& Gold, S. 2012. Conducting content-analysis based literature reviews in supply

Shauki, E. 2017. Qualitative And Mixed-Method Research Analysis Using Nvivo11.

Sutedi, A. 2014. Aspek Hukum Otoritas Jasa Keuangan. RAS. chain management. Supply Chain Management: An International Journal, 17(5), 544-555.

Tambunan, Toman S. (2019). Hukum Bisnis. Jakarta: Prenadamedia Group

Vogel, K. 1997. Klaus Vogel on double taxation conventions: A commentary to the OECD-, UN-, and US model conventions for the avoidance of double taxation on income and capital, with particular reference to German treaty practice. Kluwer law international.

Yin, R. K. 2011. Studi Kasus: Desain dan Metode. Jakarta: PT. Rajagrafindo Persada.

Zuraya, N. 2017. Soal Kewajiban Bayar Pajak, OJK Tunggu Keputusan Kemenkeu. Retrieved from https://www.republika.co.id/berita/ekonomi/keuangan/17/12/05/p0hgfz383-soal-kewajibanbayar-pajak-ojk-tunggu-keputusan-kemenkeu. 